Int. Arch. Allergy 1972;42:I-VIII

\title{
Contents, Vol. 42, 1972
}

Vol. 42,1972

International Archives of Allergy andAppliedlmmunology

Incorporating the Transactions of the Collegium Internationale Allergologicum

Founders:

P. Kallós, W. Löffler,

Fred W. Wittich, D. Harley

Editors-in-Chief: R. R. A. Coombs, Cambridge H. C. Goodman, Geneva F. Hahn, Freiburg/Br.

P. Kallós, Helsingborg P. Miescher, Geneva

F. Milgrom, Buffalo, N.Y.

G. B. West, Epsom, Surrey

Contributing Editors:

E. L. Becker, Washington, D.C.

H. Bloch, Basel

W. E. Brocklehurst, Edinburgh

T. Broman, Göteborg

L. Businco, Roma

A. Cerletti, Basel

A. L. De Weck, Bern

W. P. Faulk, Geneva

P. G. H. Gell, Birmingham

H. Gewurz, Chicago, Ill.

I. Glazer, Tel Aviv

R. A. Good, Minneapolis, Minn.

A. Grumbach, Zurich

M. Hasek, Prague

T. Inderbitzin, Bern

H. Isliker, Lausanne

E. A. Kabat, New York, N. Y.

R. Keller, Zurich

T. Ogata, Tokyo

A. Oliveira-Lima, Rio de Janeiro

Ö. Ouchterlony, Göteborg

W. Pagel, London

R. Panzani, Marseille

I. M. Roitt, London B. Rose, Montreal

D. Rowe, Lausanne

G. Ruiz-Moreno, Buenos Aires

E. Sorkin, Davos-Platz

H. Storck, Zurich 
A. Szenberg, Melbourne

G. Torrigiani, Geneva

Z. Trnka, Basel

B. H. Waksman, New Haven, Conn.

G. L. Waldbott, Detroit. Mich.

R. G. White, Glasgow

S.

S. Karger - Basel · München · Paris · London · New York · Sydney

Contents

Abreu Leme, Cid De: see Beutner, E. H.

Aguirre, A.: see Katsh, S.

Ahlstedt, S.; Holmgren, J., and Hanson, L. å.: Significance of Amount and Avidity of E. coli O Antibodies for Manifestation of their Serological and Protective Properties. A Preliminary Study $\quad 826$

Ankier, S. T. and Neat, M. L.: Some Studies on Acute Inflammation Induced by Dextran in the Mouse 264

AsseM, E. S. K.; Schild, H. O., and Vickers, Margaret R.: Stimulation of Histamine Forming Capacity by Antigen in Sensitized Human Leucocytes . 343 Attallah, N. A.: see Kisil, F. T.

Auer, I. O. and Milgrom, F.: Studies on Thermostable Liver-Specific Antigens. . 871

Auer, I. O.; Yagi, Y.; Kasukawa, R., and Milgrom, F.: A Solid-Phase Radioimmunoassay for a Thermostable Adrenal-Specific Antigen 816

Avrameas, S.: see Miller, H. R. P.

Baenkler, H. W.; Scheiffarth, F., and Mahlberg, H. J.: Inhibition of 19S- and

7S-Antibody-Formation by Adoptively Transferred Heterologous and

Homologous Immunized Cells 373

Bankhurst, A. D.; Rouse, B. T., and Warner, N. L.: Surface Immunoglobulins

on Bursa-Derived Chicken Lymphoid Cells 187

Bash, J. A. and Milgrom, F.: Studies on Allotypes in Sheep 196

Belin, L.: Immunological Analyses of Birch Pollen Antigens, with Special Refer ence to the Allergenic Components 300

Belin, L.: Separation and Characterization of Birch Pollen Antigens with Special

Reference to the Allergenic Components 329

Bencina, B.: see Whittingham, S.

Bernauer, W.; Hahn, F.; Nimptsch, P., and Wissler, J.: Studies on Heart Anaphylaxis. V. Cross-Desensitisation Between Antigen, Anaphylatoxin, and Compound 48/80 in the Guinea-Pig Papillary Muscle 136

Beutner, E. H.; Chorzelski, T. P.; Jarzabek, M.; Wood, G. W.; Abreu Leme, Cid de, and Bier, O.: Studies in Immunodermatology. I. Passive Induc tion of Intraepidermal Clefts in Rabbits by Transfer of Sera from Brazili an Pemphigus Foliaceus Patients 545

Beutner, E. H.: see Wood, G. W.

Bier, O.: see Beutner, E. H.

Binaghi, R. A.: see Perini, Adenir

Blazkovec, A. A.: see Maginn, P. C. 
Bluestone, R.; Gumpel, J. M.; Goldberg, L. S., and Holborow, E. J.: Salivary

Immunoglobulins in Sjögren's Syndrome 686

Boussac-Aron, Yolande: see Perini, Adenir

Brazil Esteves, Maria: see Perini, Adenir

Carnegie, P. R.: see Whittingham, S.

Contents

III

Centeno, E. R.: see Kisil, F. T.

Ceska, M.; Eriksson, R., and Varga, J. M.: Characterization of Allergen Extracts

by Polyacrylamide Gel Isoelectrofocusing and Radioimmunosorbent

Allergen Assay. I. Distribution of Allergenic Components in Birch Pollen

Extracts $\quad 430$

Ceska, M.: see Varga, J. M.

Chachowski, R.: see Tripodi, D.

Chi-Cheng Tsai: see Taichman, N. S.

Chickosky, Jane F.: see Hinz, C. F. jr.

Chorzelski, T. P.: see Beutner, E. H.

Chorzelski, T. P. :see Wood, G. W.

Cole, L. J. †: see Miller, J. J. Ill

Coombs, R. R. A.: see Wilson, Anne B.

Curtain, C. C. and Simons, M. J.: Lymphocyte Mitogens of Indigenous Australian

Plant Species 225

Daniel, K.: see Maginn, P. C.

DeVald, B. L.: see Tuchinda, M.

Devey, Madeleine: see Wilson, Anne B.

Eisen, A. H.: see Hubscher, T.

Erb, P.; LAZÀRY,S., and Loeffler,H.: Primary and Secondary Immune Response

Kinetics in the Syrian Hamster 362

Eriksson, R.: see Ceska, M.

Feldmann, Marc : see Lennon, Vanda

Fischer, H.: see Lohmann-Matthes, M.-L.

Foucard, T.: Immunochemical and Biological Determination of Reagins. A Com parison Between the Radioallergosorbent Test (RAST) and the Test for Histamine Release from Passively Sensitized Chopped Human Lung (CHLT) 711

Frey, J. R.; Weck, A. L. de; Geleick, N., and Polak, L.: The Induction of Immunological Tolerance During the Primary Response 278

Friedman, H.; see Sabet, T. Y.

Frommel, D.: see Linna, T. J

Gall, S. A. and Halbert, S. P.: Antigenic Constituents in Pregnancy Plasma which are Undetectable in Normal Non-Pregnant Female or Male Plasma. . 503

Galmarini, Mirian : see Pacheco-Rupil, Beatritz

Geleick, H.: see Frey, J. R.

Girard, J. P.: see Weck, A. L. de

Gleich, G. J.: see Hansen, R. L.

Goldberg, L. S.: see Bluestone, R. 
Good, R. A.: see Heim, L. R.

Good, R. A.: see Linna, T. J.

Greaves, M. W.: see Yeoh, T. S.

Greene, E. L.; Halbert, S. P., and Jequier, S.: Analysis of the Tissue Consti

tuents and Enzymes of Human Liver by Crossed Immunoelectrophoresis-

Comparison of Normal and Cystic Fibrosis Liver 751

IV

Contents

Grundbacher, F. J. and Schreffler, D. C.: Partial Immunologic Tolerance to the

Human B but not to the A Antigen 130

Gumpel, J. M.: see Bluestone, R.

Hahn, F.: see Bernauer, W.

Halbert, S. P.: see Gall, S. A.

Halbert, S. P.: see Greene, E. L.

Halbert, S. P.: see Tsue-Ming Lin

Hamnström, B and Winblad, S.: Influence of Species of Origin of Red Blood Cells

on in vitro Inhibition of Streptolysin O by Serum Lipoproteins. . . 590

Hanson, L. Å.: see Ahlstedt, S.

Hansen, R. L. and Gleich, G. J.: Immune Response to the Hemocyanin from Li-

mulus Polyphemus in Allergic and Normal Individuals 607

Hargis, Betty J.: see Malkiel, S.

Heim, L. R.; Yunis, E. J., and Good, R. A.: Pathogenesis of Graft-versus-Host

Reaction. 11. Influence of Thymectomy and Adrenalectomy on Lymphoid

Tissue Pathology; Delineation of Nonthymus-Dependent Lymphoid

Elements $\quad 565$

Hemmingsson, E. J. and Linna, T. J.: Ontogenetic Studies on Lymphoid Cell Traffic in the

Chicken. I. Cell Migration from the Bursa of Fabricius. . . 693

Hemmingsson, E. J.: Ontogenetic Studies on Lymphoid Cell Traffic in the Chicken.

II. Cell Traffic from the Bursa of Fabricius to the Thymus and the Spleen

in the Embryo 764

Henderson, D.: see Jarrett, Ellen E. E.

Hinz, C. F. jr. and Chickosky, Jane F.: Factors Influencing the Stimulation of

Human Lymphocytes by Antigen during Culture in vitro. Conditions for

Lymphocyte Stimulation $\quad 836$

Holborow, E. J.: see Bluestone, R.

Holmgren, J.: see Ahlstedt, S.

Hubscher, T. and Eisen, A. H.: Localization of Ragweed Antigens in the Intact

Ragweed Pollen Grain 466

Inman, J. K.: see Rouquès, Renée

Jarrett, Ellen E. E.; Henderson, D.; Riley, Patricia, and White, R. G.: The

Effect of Various Adjuvant Regimens and of Nematode Infection on the

Reaginic Antibody Response to Egg-Albumin in the Rat 775

Jarzabek, M.: see Beutner, E. H.

Jequier, S.: see Greene, E. L.

Juji, T.; Kano, K., and Milgrom, F.: Mixed Agglutination with Platelets. . . 474

Kågedal, L.: see Richter, W. 
Kano, K.: see Juji, T.

Kasukawa, R.: see Auer, I. O.

Katsh, F. G.: see Katsh, S.

Katsch, S.; Aguirre, A.; Willson, J. T., and Katsh, G. F.: Aspermatogenesis.

Exploration as a Model for Auto-Allergic Diseases 169

Kisil, F. T.; Centeno, E. R.; Attallah, N. A., and Sehon, A. H.: Demonstration

of Reagin-Allergen Complexes Formed on Elution of Reagins from Im-

munosorbent with Allergens 40

Contents

$\mathrm{V}$

Koren, H. S.: see Lohmann-Matthes, M.-L.

Krogh, H. K.; Maeland, J. A., and Tönder, O.: Indirect Haemagglutination for

Demonstration of Antibodies to Stratum Corneum of Skin 493

Lavallée, A.: see Perelmutter, L.

Lazàry, S.: see Erb, P.

Lennon, Vanda and Feldmann, Marc : The Detection of Autoantibody-Forming

Cells. I. An Assay for Plaque-Forming Cells to the Basic Protein of

Myelin in Guinea-Pigs 627

Levine, L.: see Pieroni, R. E.

Levy, D. A.: see Lichtenstein, L. M.

Liacopoulos, P.: see Merchant, B.

Lichtenstein, L. M. and Levy, D. A.: Is ‘Desensitization' for Ragweed Hay Fe

ver Immunologically Specific?

615

Linna, T. J.; Frommel, D., and Good, R. A.: Effects of Early Cyclophosphamide

Treatment of the Development of Lymphoid Organs and Immunologícal

Functions in the Chicken 20

Linna, T. J.: see Hemmingsson, E. J.

Loeffler, H.: see Erb, P.

Lohmann-Matthes, M.-L.; Koren, H. S., and Fischer, H.: Kinetics of the in

vitro Development of Cytotoxicity against Alloantigens 110

Mach, J.-P.: see Pahud, J.-J.

Maeland, J. A.: see Krogh, H. K.

Maginn, P. C; Daniel, K.; Sparr, L., and Blazkovec, A. A.: Further Studies

on Guinea Pig and Rabbit Cytophilic Antibodies Directed Against

Human Serum Albumin. I. The Immune Response Following Sensitiza-

tion with Antigen- Antibody Complexes 382

Maginn, P. C; Sparr, L.; Daniel, K., and Blazkovec, A. A.: Further Studies

on Guinea Pig and Rabbit Cytophilic Antibodies Directed Against Human

Serum Albumin. II. Ir vitro Binding Properties and the Role of Cytophi

lic Antibody in Plaque-Formation as Measured Using the Indirect Techni

que of Localized Hemolysis in Gel 399

Mahlberg, H. J.: see Baenkler, H. W.

Maillard, J. L.; Pick, E., and Turk, J. L.: Interaction Between 'Sensitized Lym

phocytes' and Antigen in vitro. V. Vascular Permeability Induced by

Skin-Reactive Factor 50

Malkiel, S. and Hargis, Betty J.: Adjuvance in the Cebus Monkey 323 
Marchand, Rose-Mary: see Wilson, Anne B.

Mathews, K. P.; Pan, Pauline M., and Wells, J. H.: Experience with Lymphocyte

Transformation Tests in Evaluating Allergy to Aminosalicylic Acid, Iso-

niazid and Streptomycin 653

McEwen, L. M. and Starr, M.S.: Enzyme-Potentiated Hyposensitisation.I.The Effect of Pre-

treatment with /?-Glucuronidase, Hyaluronidase, and Antigen on Anaphylactic Sensitivity of

Guinea-Pigs, Rats and Mice.... 152

McKee, A. P.: see Tripodi, D.

McPherson, A.: see Whittingham, S.

Mehrishi, J. N.: Surface Molecular Components of Human Lymphocytes.... 69

VI

Contents

Merchant, B. and Liacopoulos, P.: Paradoxical Cellular and Serologic Responses

following Antigenic Competition 516

Merchant, B.: see Rouquès, Renée

Milgrom, F.: see Auer, I. O.

Milgrom, F.: see Bash, J. A.

Milgrom, F.: see Tuji, T.

Miller, H. R. P. and Avrameas, S.: Ultrastructural Localisation of Antigen in

Plasma Cells 353

Miller, J. J. Ill and Cole, L. J. †: Studies of Non-Migrating, Long-Lived Lym

phocytes in Rats and Mice. II. Effects of Anti-Lymph Node and Anti-

Thymus Antisera 118

Muir, J. D.: see Ranadive, N. S.

Neat, M. L.: see Ankier, S. I.

Newcomb, R. W.: see Tuchinda, M.

Nimptsch, P.: see Bernauer, W.

Oriol, R.: see Perini, Adenir

Pacheco-Rupil, Beatritz; Yantorno, C, and Galmarini, Mirian: Antibody

Response to Phytohaemagglutinin in Rats 596

Pahud, J.-J. and Mach, J.-P.: Equine Secretory IgA and Secretory Component. . 175

Pan, Pauline M.: see Mathews, K. P.

Paskewitz, A.: see Tsue-Ming Lin

Perelmutter, L.; Lavallée, A., and Wiberg, G. S.: The Effect of Laundry Deter

gent Containing B. subtilis Enzyme in Producing Sensitization Reactions

in Guinea Pigs 215

Perini, Adenir; Binaghi, R. A.; Boussac-Aron, Yolande; Orid, R., and Brazil

Esteves, María: Heterogeneity of Guinea Pigyi and y\% Immunoglobulins 8

Pick, E.: see Maillard, J. L.

Pieroni, R. E.; Stevens, D. L.; Stojanovic, A. and Levine, L.: Investigation of the Responsiveness of BCG-Vaccinated Children with Whooping-Cough

to Tuberculin 583

Polak, L.: see Frey, J. R.

Pollack, W.: see Tripodi, D.

Pomeranz, J. R.: see Silverman, A. S. 
Ranadive, N. S. and Muir, J. D.: Similarity in the Mechanism of $\mathrm{Hi}^{1} / 8 \operatorname{tamine} \mathrm{Re}$ lease Induced by Cationic Protein from Neutrophils and by Complement Dependent Ag-Ab Reaction 236

Redecker, A.: see Tripodi, D.

Richter, W. and Kågedal, L.: Preparation of Dextran-Protein Conjugates and Studies of their Immunogenicity 885

Riley, Patricia: see Jarrett, Ellen E. E.

Rouquès, Renée; Inman, J. K. and Merchant, B.: Detection of Cells Secreting Antibodies more Reactive with an Alternate Structure than with the Im munizing Hapten 852

Rouse, B. T.: see Bankhurst, A. D.

Sabet, T. Y. and Friedman, H.: Antibody Plaque Formation in vitro in the Pre sence of Respiration Inhibitors 161

Contents VII

Scheiffarth, F.: see Baenkler, H. W.

Schneider, C. H.: see Weck, A. L. De

Schreffler, D. C.: see Grundbacher, F. J.

Sehon, A. H.: see Kisil, F. T.

Shild, H. O.: see AsseM, E. S. K.

SilverMan, A. S. and Pomeranz, J. R.: Studies on the Localization of Hapten in Guinea Pigs Picryl Chloride 1

Simons, M. J.: see Curtain, C. C.

Sorkin, E.: see Wissler, j. H.

Sparr, L.: see Maginn, P. C.

Starr, M. S.: see McEwen, L. M.

Stecher, V. J.: see Wissler, J. H.

Stevens, D. L.: see Pieroni, R. E.

Stojanovic, A.: see Pieroni, R. E.

St. Pierre, R. L.: see Toben, H. R.

Sundqvist, K. G.: Reactivity of Sera from Patients with Renal and Liver Diseases with Membrane Antigens on Monkey Kidney Cells 641

Taichman, N. S. and Chi-Cheng Tsai: Heterophile Antibodies and Tissue Injury. II. Ultrastructure of Dermal Vascular Lesions Produced by Forssman

Antiserum in Guinea Pigs 78

Tay, C. H.: see Yeoh, T. S.

Toben, H. R. and St. Pierre, R. L.: Alteration of Immunological Reactivity in Chickens by the in ovo Administration of Antisera Against Central Lymphoid Tissue 454

Tönder, O.: see Krogń, H. K.

Tripodi, D.; Redecker, A.; McKee, A. P.; Chachowski, R., and Pollack, W.:

A Comparative Clinical Evaluation of Hepatitis-Associated Antigen De tection. I. Hepatitis-Associated Antigen Detection among Liver Disease Patients 681

Tsue-Ming Lin; Halbert, S. P., and Paskewitz, A.: The Cardiac Auto-Immune System. V. Human Heart Antigens Cross-Reactive with Rabbit Anti-

Rabbit Heart Auto-Antibodies 
Tuchinda, M.; Newcomb, R. W., and DeVald, B. L.: Effect of Prednisone Treatment on the Human Immune Response to Keyhole Limpet Hemocyanin 533

Turk, J. L.: see Maillard, J. L.

Varga, J. M. and Ceska, M.: Characterization of Allergen Extracts by Polyacrylamide Gel Isoelectrofocusing and Radioimmunosorbent Allergen Assay.

II. Dog and Cat Allergens 438

Varga, J. M.: see Ceska, M.

Vickers, Margaret, R.: see Assem, E. S.K.

Warner, N. L.: see Bankhurst, A. D.

Weck, A. L. De and Schneider, C. H.: Specific Inhibition of Allergic Reactions

to Penicillin in Man by a Monovalent Hapten. I. Experimental Immuno

logical and Toxicologic Studies $\quad 782$

Weck, A. L. De and Girard, J. P.: Specific Inhibition of Allergic Reactions to

Penicillin in Man by a Monovalent Hapton. II. Clinical Studies. . . 798

VIII

Contents

Weck, A. L.: see Frey, J. R.

Wells, J. H.: see Mathews, K. P.

Went. Maria: see Csaba, B.

White, R. G.: see Jarrett, Ellen, E. E.

Whittingham, S; Bencina, B; Carnegie, P. R., and M $\gamma$ Pherson, T. A.: Proper

ties of Antibodies Produced in Rabbits to Human Myelin and Myelin

Basic Protein 250

Wiberg, G. S.: see Perelmutter, L.

Willson, J. T.: see Katsh, S.

Wilson, Anne B.; Marchand, Rose-Mary; Wilson, D. V.; Devey Madeleine, and Coombs, R. R. A.: Reaginic Antibodies on Basophils in Grass Pollen

Allergy, as shown by Rosette-Formation 668

Wilson, D. V.: see Wilson, Anne B.

Winblad, S.: see Hamnström, B.

Wissler, J. EL; Stecher, V. J., and Sorkin, E.: Biochemistry and Biology of a

Leucotactic Binary Serum Peptide System Related to Anaphylatoxin . 722

Wissler, J.: see Bernauer, W.

Wood, G. W.; Beutner, E. H., and Chorzelski, T. P.: Studies in Immunoder-matology. II.

Production of Pemphigus-Like Lesions by Intradermal Injection of Monkeys with Brazilian

Pemphigus Foliaceus Sera .... 556

Wood, G. W.: see Beutner, E. H.

World Health Organization Technical Report Series No. 496. Clincial Im

munology. Report of a WHO Scientific Group after 750

Yagi, Y.: see Auer, I. O.

Yantorno, C.: see PacheoxRupil, Beatritz

Yeoh, T. S.; Tay, C. H., and Greaves, M. W.: Anaphylactic Release of Histamine

from Guinea Pig Skin in vitro 485

Yunis, E. J.: see Heim, L. R.

Letter to the Editors 748

Book Reviews 159,328,491 
News Items 492

Erratum 492

S. Karger · Basel · München · Paris · London · New York · Sydney Arnold-Böcklin-Strasse25, CH-4000 Basel 11 (Switzerland)

All rights, including that of translation into other languages, reserved.

Photomechanic reproduction (photocopy, microcopy) of this book or parts thereof without special permission of the publishers prohibited.

(C) Copyright 1972 by S. Karger AG, Verlag für Medizin und Naturwissenschaften, Basel Printed in Switzerland by Buchdruckerei National-Zeitung AG, Basel 